\title{
STRATEGI PENGELOLAAN ZAKAT DALAM PENGENTASAN KEMISKINAN
}

\author{
Irsyad Andriyanto \\ STAIN Kudus \\ e-mail: irsyad_andriyanto@yahoo.co.id
}

\begin{abstract}
In Islam institutionalized poverty eradication with the charity. Therefore, charity should be managed in a productive and professional so that zakat has participation in realizing the ideals of Islam to the life of a prosperous people. One of the management institutions in Indonesia to manage zakat zakat with trustworthy, transparent, and professional is the Rumah Zakat Indonesia (RZI). This study uses socio-economic approach. The analysis serves to simplify data into a form that is easier to read and interpret. The analysis used in this research is descriptive analysis.

$* * *$

Dalam Islam upara pengatasan kemiskinan adalah dengan zakat. Oleh karena itu, zakat seharusnya dikelola secara produktif dan profesional sehingga zakat dapat mengambil bagian dalam merealisasikan ide-ide Islam untuk mensejahterakan masyarakat Saah satu lembaga yang terbukti telah mampu mengelola zakat secara terpercaya, transparan, dan profesional adalah Rumah Zakat Indonesia (RZI). Kajian ini menggunakan pendekatan sosial-ekonomi, Analisis yang yang digunakan bertujuan untuk mempermudah data ke dalam bentuk yang lebih mudah untuk dibaca dan diinterpretasikan. Analisis yang digunakan dalam kajian ini adalah analisis deskriptif.
\end{abstract}

Keywords: zakat, infak dan shadaqah, RZI, HealthCare, EduCare, EcoCare, YouthCare 


\section{A. Pendahuluan}

Dalam konteks menyikapi perkembangan kemiskinan di Indonesia, selama tahun 1976-1996 jumlah penduduk miskin turun drastis dari 54 juta jiwa atau 40\% dari jumlah penduduk (1976) turun menjadi 22,5 juta jiwa atau sekitar 11,3\% (1996). Sejak adanya krisis ekonomi tahun 1998 meningkat 400\%, pada tahun 1997 dari 22 juta jiwa menjadi 80 juta jiwa (BPS, 2005). Di Jawa Tengah kondisi kemiskinan rata-rata menunjukkan peningkatan dari 5,9 juta jiwa pada tahun 2003 menjadi 6,9 juta jiwa di tahun 2006 (Susenas). Meningkatnya jumlah penduduk miskin merupakan bahaya besar bagi umat manusia dan tidak sedikit umat yang jatuh peradabannya hanya karena kefakiran, oleh karena itu diperlukan suatu kebijakan dalam pemberantasan kemiskinan.

Dalam Islam, pemberantasan kemiskinan dilembagakan dalam salah satu rukunnya, yaitu zakat, ${ }^{1}$ oleh karena itu diperlukan pengelolah zakat yang amanah, transparan, dan profesional. Salah satu dari sekian banyak organisasi yang mengelola zakat secara efektif, efisien dan transparan adalah Rumah Zakat Indonesia (RZI). ${ }^{2}$ Untuk memaksimalkan pemberdayaan masyarakat, maka didirikanlah unit-unit layanan sebagai sentra optimalisasi 4Care: 4 Sekolah Juara, 5 Rumah Bersalin Gratis, 13 Layanan Bersalin Gratis, 17 Lembaga Keuangan Mikro Syariah (LKMS) Mozaik, dan 2 Youth Development Centre (YDC). ${ }^{3}$ Pada saat ini tercatat 64.222 donatur yang bergabung di RZI dan didukung 656 amil dengan fungsi mulai dari back office, tenaga funding, hingga personil program. Sehingga EcoCare melalui LKMS Mozaik telah mampu membukukan 5.550 orang anggota, dengan 912 orang peserta KUKMI (Kelompok Usaha Kecil Mandiri) dan dana bergulir senilai Rp 6,4 M. Begitu juga YouthCare telah mencatat 1.153 relawan bergabung dengan 914 relawan aktif. Aktivitas Kampus Relawan yang berjalan di 10 kota, meng-

${ }^{1}$ Abdurrachman Qadir, Zakat dalam Dimensi Mahdah dan Sosial, (Jakarta: Raja Grafindo Persada, 2001), h. 83-84.

${ }^{2}$ Rumah Zakat Indonesia (RZl) adalah sebuah lembaga amil zakat nasional yang memfokuskan pada pengelolaan zakat, infaq, shadaqah dan wakaf secara lebih profesional dengan menitikberatkan program pendidikan, kesehatan, pembinaan komunitas dan pemberdayaan ekonomi sebagai penyaluran program unggulan. Lihat, Rumah Zakat Indonesia, "Profil Rumah Zakat Indonesia," dikutip dari http://www.rumahzakat.org, diakses pada tanggal 23 Maret 2011.

${ }^{3}$ Ibid. 
gulirkan kurikulum Community Development, Emergency Resque Team, dan Pendampingan Masyarakat yang memberi nilai manfaat bagi 2.112 warga. Tidak ketinggalan HealthCare dengan 32 armada ambulan dan mobil jenazah, 6 armada mobil klinik keliling, telah merekam 94.397 peserta Aksi Siaga Sehat. ${ }^{4}$

Oleh karena itu penelitian dilakukan pada pengelolaan zakat RZI sangat variatif, bahkan terkesan jauh dari alokasi distribusi zakat konvensional yang secara ketat tidak boleh beranjak dari kedelapan așnaf yang ada. Hal ini menunjukkan dengan jelas bahwa lembaga ini telah berupaya agar alokasi dan distribusi zakat dapat diimplementasikan secara efektif, efisien dan tepat sasaran dalam pengentasan kemiskinan khususnya di Provinsi Jawa Tengah. Dari latar belakang masalah di atas, maka permasalahan penelitian ini adalah tentang faktor-faktor yang mempengaruhi motivasi masyarakat menyalurkan zakat (dan juga infaq, shadaqah dan wakaf) di Rumah Zakat Indonesia dan bagaimana pengelolaan zakat yang dilakukan oleh Rumah Zakat Indonesia (RZI) dalam pengentasan kemiskinan di Jawa Tengah.

Penelitian ini menggunakan pendekatan kualitatif. Adapun objek penelitian yang akan dijadikan wilayah penelitian adalah Rumah Zakat Indonesia di Jawa Tengah sebagai batas wilayah penelitian dengan melihat pada pengelolaan dan pendistribusian zakat sebagai upaya pengentasan kemiskinan. Penelitian ini juga merupakan penelitian evaluatif ditinjau dari sudut bentuknya. Oleh karenanya, penelitian ini akan menganalisis program pendistribusian zakat dalam upaya pengentasan kemiskinan di Jawa Tengah.

Penelitian ini hanya akan meneliti sebagian populasi dari seluruh anggota Rumah Zakat Indonesia (RZI) yang meliputi muzakki, pengelola dan mustahiq zakat. Adapun metode penentuan sampel yang akan digunakan adalah purposive sampling. Sampel diambil dari sebagian yang dapat mewakili untuk memberikan informasi yang akan dibutuhkan baik dari pihak muzakki, mustahiq dan pengelolah zakat yang ditentukan sebagai objek dari penelitian ini.

Adapun responden dari Rumah Zakat Indonesia yaitu pengurus bidang pelaksana yang meliputi ketua, sekretaris, bendahara dan semua divisinya. Selain itu, wawancara melibatkan unsur pemerintah untuk memperoleh data

${ }^{4}$ Ibid. 
tentang kondisi daerah penelitian, di samping memperoleh data dari kalangan muzakki dan mustahiq yang telah ditentukan sebagai responden.

Analisis berfungsi untuk menyederhanakan data ke dalam bentuk yang lebih mudah dibaca dan diinterpretasikan. ${ }^{5}$ Adapun analisis yang dipakai dalam penelitian ini adalah deskriptif analisis kualitatif yaitu penelitian yang bertujuan untuk mengumpulkan data-data yang dikumpulkan untuk dianalisis yang kemudian data-data tersebut diinterpretasikan lalu diambil suatu kesimpulan.

\section{B. Konsep Kemiskinan}

Menurut UNICEF, kemiskinan sebagai ketidakmilikan hal-hal secara materi kebutuhan minimal manusia termasuk kesehatan, pendidikan dan jasajasa lainnya yang dapat menghindarkan manusia dari kemiskinan. Ravalion menyatakan dalam dekade 1970-an merumuskan garis kemiskinan (poverty line) untuk menetukan tingkat pendapatan minimum yang cukup untuk memenuhi kebutuhan fisik dasar setiap orang berupa kebutuhan makan, pakaian serta perumahan sehingga dapat menjamin kelangsungan hidupnya. ${ }^{6}$

Blank menguraikan konsep tentang karakteristik lokal yang berpotensi mempengaruhi tingkat kemiskinan dan kebijakan yang mempengaruhinya. karakteristik tersebut adalah: lingkungan alamiah, struktur ekonomi, kelembagaan dan karakteristik penduduk suatu daerah lokal.7 World Bank menjelaskan beberapa karakteristik penduduk miskin diantaranya: gizi buruk, rendahnya pendidikan, umur harapan hidup dan standar perumahan. Sepuluh tahun kemudian World Bank mengeluarkan laporan tentang memerangi kemiskinan yang menekankan pada karakteristik lain yaitu pada umumnya mereka memiliki kedudukan yang lemah dalam menyuarakan kepentingannya dan rentan terhadap gejolak ekonomi. ${ }^{8}$

\footnotetext{
${ }^{5}$ Sofyan Effendi, "Prinsip-prinsip Analisa Data," dalam Masri Singarimbun, Metode Penelitian Survei, (Jakarta: LP3ES, 1988), h. 213.

${ }^{6}$ Ravallion, M., Poverty Comparisons, World Bank, 2001, h. 10.

${ }^{7}$ Blank, "Poverty, Policy and Palce : How Poverty and Policies to Alleviate Poverty are Shaped by Local Characteristics," RPRC Working Paper, 2004, pp. 4-12

${ }^{8}$ World Bank, World Bank Report, 2000/2001: Attacking Poverty, (Oxford: Oxford University Press, 2001), pp. 29-38.
} 
Badan Perencanaan Pembangunan Nasional (Bappenas) menjelaskan kemiskinan adalah situasi serba kekurangan yang terjadi bukan karena dikehendaki oleh si miskin, melainkan karena tidak dapat dihindari dengan kekuatan yang ada padanya. ${ }^{9}$ Pendapat lain dikemukakan oleh Ali dalam Setyawan yang menyatakan kemiskinan adalah adanya gap atau jurang antara nilai-nilai utama yang diakumulasikan dengan pemenuhan kebutuhan akan nilai-nilai tersebut secara layak. ${ }^{10}$ Menurut Chambers dalam Ali ${ }^{11}$ ada lima ketidakberuntungan yang melingkari kehidupan orang miskin yaitu: (1) Kemiskinan (poverty), memiliki tanda-tanda sebagai berikut: rumah reot dan dibuat dari bahan bangunan yang bermutu rendah, perlengkapan yang sangat minim, ekonomi keluarga ditandai dengan ekonomi gali lubang tutup lubang serta pendapatan yang tidak menentu; (2) Masalah kerentanan (vulnerability), kerentanan ini dapat dilihat dari ketidakmampuan keluarga miskin menghadapi situasi darurat. Perbaikan ekonomi yang dicapai dengan susah payah sewaktu-waktu dapat lenyap ketika penyakit menghampiri keluarga mereka yang membutuhkan biaya pengobatan dalam jumlah yang besar; (3) Masalah ketidakberdayaan (powerlessness). Bentuk ketidakberdayaan kelompok miskin tercermin dalam ketidakmampuan mereka dalam menghadapi elit dan para birokrasi dalam menentukan keputusan yang menyangkut nasibnya, tanpa memberi kesempatan untuk mengaktualisasi diri; (4) Lemahnya ketahanan fisik (physical weakness) karena rendahnya konsumsi pangan baik kualitas maupun kuantitas sehingga konsumsi gizi mereka sangat rendah yang berakibat pada rendahnya produktivitas mereka dan (5) Masalah keterisolasian (isolation), keterisolasian fisik tercermin dari kantong-kantong kemiskinan yang sulit dijangkau, sedangkan keterisolasian sosial tercermin dari ketertutupan dalam integrasi masyarakat miskin dengan masyarakat yang lebih luas.

Sedangkan menurut Kuncoro ${ }^{12}$ bahwa dari sisi ekonomi, kemiskinan itu terjadi karena disebabkan tiga hal, antara lain: adanya ketidaksamaan pola

9 Bappenas, Perspektif Teoritis Konsep Dasar Pengembangan Ekonomi Lokal, Uakarta: Bappenas, 1993), h. 3.

${ }^{10}$ Setyawan, Setu, Pengukuran Kinerja Anggaran Keuangan Daerah Pemerintah Dilihat dari PrespektifAkuntabilitas, (Yogyakarta: UGM, 2006), h. 120.

${ }^{11}$ Ali, Nuruddin M., "Zakat (Pajak) sebagai Instrumen dalam Kebijakan Fiskal," Tesis, tidak diterbitkan, (Yogyakarta: Program Pascasarjana IAIN Sunan Kalijaga 2003), h. 18.

12 Mudrajad Kuncoro, Ekonomi Pembanguan: Teori, Masalah, dan Kebijakan, (Yogyakarta: UPP AMP-YKPN, 2003), h. 107. 
kepemilikan sumber daya yang menimbulkan distribusi pendapatan timpang, perbedaan kualitas sumber daya manusia, kualitas sumber daya manusia yang rendah menunjukkan produktivitas rendah, upah rendah dan perbedaan akses dan modal. Ketiga penyebab kemiskinan tersebut di atas bermuara pada teori lingkaran setan kemiskinan (vicious circle of poverty).

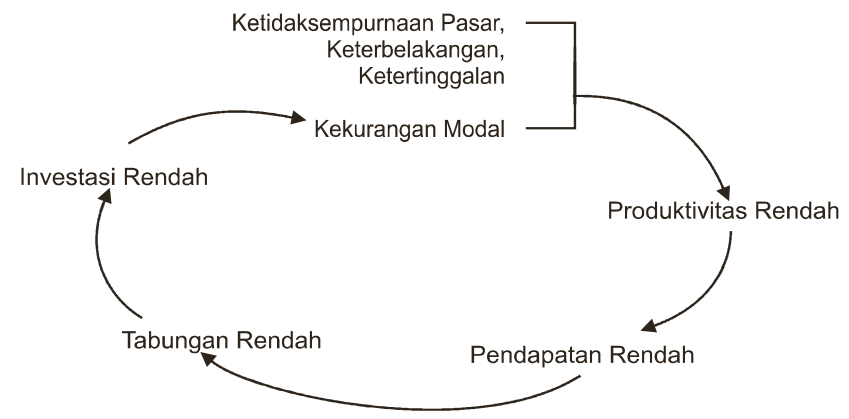

\section{Gambar 1.}

Lingkaran Setan Kemiskinan (The Vicious Circle of Poverty)

Adanya keterbelakangan, ketertinggalan, ketidaksempurnaan pasar, kurangnya modal menyebabkan rendahnya produktivitas. Rendahnya produktivitas mengakibatkan rendahnya pendapatan yang mereka terima. Rendahnya pendapatan akan berimplikasi pada rendahnya tabungan dan investasi, rendahnya investasi akan berakibat pada keterbelakangan dan seterusnya. Logika berpikir yang dikemukakan Nurkse yang dikutip Kuncoro, mengemukakan bahwa negara miskin itu miskin karena dia miskin (a poor country is poor because it is poor). ${ }^{13}$

\section{Zakat}

Ditinjau dari segi bahasa kata zakat merupakan kata dasar dari zaka yang berarti suci, berkah, tumbuh dan terpuji. Sedangkan dari segi istilah fiqh, zakat berarti sejumlah harta tertentu yang diwajibkan Allah diserahkan

${ }^{13}$ Abdurrachman Qadir, Zakat dalam Dimensi Mahdah dan Sosial, h. 7. 
kepada orang yang berhak menerimanya, disamping berarti mengeluarkan jumlah tertentu itu sendiri. ${ }^{14}$ Menurut etimologi (istilah) syariat, zakat adalah nama bagi sejumlah harta tertentu yang telah mencapai syarat tertentu yang diwajibkan Allah untuk dikeluarkan dan diberikan kepada orang-orang yang berhak menerimanya.

Zakat adalah salah satu rukun Islam yang berdimensi keadilan sosial kemasyarakatan. Secara etiomologi zakat berarti suci, baik, tumbuh, bersih dan berkembang, dan secara terminologi zakat adalah sejumlah harta yang diwajibkan oleh Allah diambil dari harta orang-orang tertentu (aghniyā) untuk diberikan kepada orang-orang yang berhak menerimanya dengan syaratsyarat tertentu. ${ }^{15}$ Esensi dari zakat adalah pengelolaan dana yang diambil dari aghniy $\bar{a}^{16}$ untuk diserahkan kepada yang berhak menerimanya ${ }^{17}$ dan bertujuan untuk mensejahterakan kehidupan sosial kemasyarakatan umat Islam. ${ }^{18}$ Hal tersebut setidaknya tercermin dari firman-firman Allah yang berkaitan dengan perintah zakat. Selain itu, diperkuat pula dengan perintah Nabi Muhammad SAW kepada Mu'adz bin Jabal yang diperintahkan untuk mengambil dan mengumpulkan harta (zakat) dari orang-orang kaya yang kemudian dikembalikan kepada fakir miskin dari kelompok mereka. Oleh karena itu dapat disimpulkan bahwa peran strategis daripada zakat bagi masyarakat itu antara lain sebagai berikut: ${ }^{19}$ (1) Capital, menurut penelitian yang dilakukan PIRAC (Public Interest Research and Advocacy) bahwa potensi zakat di Indonesia berkisar 19-20 triliun per tahun, sebuah modal yang cukup bagi pembangunan masyarakat, dan jumlah itu akan semakin besar seiring meningkatnya kesadaran umat Islam tentang zakat dan kemampuan fiqh untuk men-

${ }^{14}$ Yusuf Qardhawi, Kiat Islam Mengentaskan Kemiskinan, terjemahan, (Jakarta: Gema Insani Press, 1995), h. 34.

${ }^{15}$ Lihat: Yusuf al-Qaradhawi, ibid., h. 32, Sayyid Sabiq, Fiqh al-Sunnah, Jilid I, (Beirut: Dar al-Fikr, 1982), h. 276, Ali Ibn Muhammad al-Jurjani, Kitab al-Ta'rif, (Beirut: Dar Kutub al-'Ilmiyah, 1983), h. 114.

${ }^{16}$ QS. al-Taubah [9]: 103, artinya: "Ambillah zakat dari sebagian harta mereka, dengan zakat itu kamu membersihkan dan mensucikan mereka."

${ }^{17}$ QS. al-Taubah [9]: 60, artinya: "Sesungguhnya zakat-zakat itu, hanyalah untuk orang-orang fakir, orang-orang miskin, pengurus-pengurus zakat, para mu'allaf yang dibujuk hatinya, untuk (memerdekakan) budak, orang-orang yang berhutang, untuk jalan Allah dan untuk mereka yuang sedang dalam perjalanan."

${ }^{18}$ QS. al-Dzariyat [51]: 19, artinya: "Dan pada harta-harta mereka ada hak untuk orang miskin yang meminta dan orang miskin yang tidak mendapat bagian."

19 Lihat, DSNI Amanah, “Dapatkah Zakat Menyelesaikan Kemiskinan,” dikutip dari http://www.dsniamanah.or.id, diakses pada tanggal 10 Oktober 2010. 
deskripsikan jenis-jenis usaha/penghasilan baru yang dimasukkan sebagai objek zakat; (2) Social Justice, pelaksanaan zakat membangkitkan keadilan sosial di tengah masyarakat, disamping karena munculnya sumber-sumber penerimaan zakat dari jenis-jenis penghasilan baru juga karena zakat diberdayakan untuk kepentingan fakir-miskin yang ditunaikan oleh orang-orang kaya di tengah-tengah mereka; (3) Social Equilibrium, keseimbangan sosial yang dibangun oleh zakat menjadikan fakir mendapat bagiannya yang diperoleh dari sebagian kekayaan orang-orang kaya yang ada disekitarnya, sehingga kesenjangan sosial tidak terpaut tinggi; (4) Social Guarantee, masyarakat merasa mendapat jaminan ketika zakat bisa diwujudkan dalam bentuknya, sehingga fakir miskin tidak perlu khawatir untuk berobat atau mendapatkan pelayanan pendidikan karena tiadanya uang jaminan misalnya; (5) Social Safety, sesungguhnya dengan terhimpunnya dana zakat yang besar disamping sebagai modal pembangunan, juga bermanfaat bagi dana siaga yang siap digunakan setiap saat terutama terhadap kejadian-kejadian di luar dugaan baik bencana alam, kebakaran, banjir dan lain-lain.

\section{Kajian Riset Sebelumnya}

Zakat sudah sejak lama senantiasa menjadi objek studi yang menarik. Oleh karenanya berbagai studi seputar zakat sudah cukup banyak dilakukan, baik pada dataran teoritik maupun pada dataran empirik. Untuk mengetahui sejauh mana kemajuan tentang studi-studi yang telah dilakukan tentang seputar zakat itu, maka penulis melakukan survey terhadap studi-studi yang dapat diakses. Dari hasil survey terhadap beberapa penelitian seputar zakat, secara umum dapat disimpulkan bahwa maju dan berkembang dengan pengelolaan zakat dapat memberikan kontribusi yang signifikan terhadap pembangunan sosial dan ekonomi. Beberapa penelitian terdahulu tentang zakat dapat dilihat pada tabel berikut:

\begin{tabular}{|c|l|l|l|l|}
\hline No. & \multicolumn{1}{|c|}{$\begin{array}{c}\text { Nama } \\
\text { Peneliti }\end{array}$} & \multicolumn{1}{|c|}{ Judul } & $\begin{array}{c}\text { Tempat } \\
\text { Penelitian }\end{array}$ & \multicolumn{1}{|c|}{ Kesimpulan } \\
\hline 1 & $\begin{array}{l}\text { Emmy } \\
\text { Hamidiyah } \\
(2004)\end{array}$ & $\begin{array}{l}\text { Analisis Faktor-faktor yang } \\
\text { Mempengaruhi Pengum- } \\
\text { pulan Zakat, Infak, Sedekah } \\
\text { Wakaf dan Kurban pada } \\
\text { Lembaga Pengelola Zakat }\end{array}$ & $\begin{array}{l}\text { Dompet } \\
\text { Dhu'afa } \\
\text { Republika, } \\
\text { Muzakki }\end{array}$ & $\begin{array}{l}\text { Faktor-faktor yang diteliti } \\
\text { meliputi biaya promosi, } \\
\text { jaringan, regulasi dan mo- } \\
\text { men bulan Ramadhan } \\
\text { berpengaruh 75.5\% atas }\end{array}$ \\
\hline
\end{tabular}




\begin{tabular}{|c|c|c|c|c|}
\hline & & $\begin{array}{l}\text { (Studi Kasus: Dompet } \\
\text { Dhu'afa Republika) }\end{array}$ & & pengumpulan ZISWK \\
\hline 2 & $\begin{array}{l}\text { Husnul } \\
\text { Khatimah } \\
(2004)\end{array}$ & $\begin{array}{l}\text { Pengaruh Zakat Produktif } \\
\text { terhadap Peningkatan Ke- } \\
\text { sejahteraan Ekonomi Para } \\
\text { Mustahiq }\end{array}$ & $\begin{array}{l}\text { Dompet } \\
\text { Dhu'afa' } \\
\text { Republika, } \\
\text { Mustahiq }\end{array}$ & $\begin{array}{l}\text { Program pembiayaan } \\
\text { baik melalui skim maupun } \\
\text { pembiayaan bagi hasil ter- } \\
\text { bukti memberikan man- } \\
\text { faat dengan adanya pe- } \\
\text { ningkatan penghasilan } \\
\text { dan kemampuan ber- } \\
\text { usaha mitra }\end{array}$ \\
\hline 3 & $\begin{array}{l}\text { Agus } \\
\text { Lukman } \\
\text { Hakim } \\
\text { (2004) }\end{array}$ & $\begin{array}{l}\text { Persepsi Karyawan dan } \\
\text { Relawan terhadap Efektivi- } \\
\text { tas Aspek-aspek Organisasi } \\
\text { Pengelolaan Zakat dalam } \\
\text { Pendistribusian ZIS }\end{array}$ & $\begin{array}{l}\text { Rumah } \\
\text { Zakat } \\
\text { Indonesia, } \\
\text { Amil }\end{array}$ & $\begin{array}{l}\text { Aspek-aspek organisasi } \\
\text { RZI cabang Jakarta dan } \\
\text { pelaksanaan program pe- } \\
\text { layanan dinilai positif oleh } \\
\text { para responden (relawan- } \\
\text { amil) }\end{array}$ \\
\hline 4 & $\begin{array}{l}\text { Umrotul } \\
\text { Khasanah } \\
(2003)\end{array}$ & $\begin{array}{l}\text { Analisis Model Pengelolaan } \\
\text { Dana Zakat di Indonesia } \\
\text { (Kajian terhadap BAZ dan } \\
\text { LAZ) }\end{array}$ & $\begin{array}{l}11 \text { LAZ } \\
\text { Nasional } \\
\text { dan } 2 \text { BAZ }\end{array}$ & $\begin{array}{l}\text { Klasifikasi, sifat, struktur } \\
\text { organisasi dari Amil Zakat } \\
\text { yang berbeda-beda. }\end{array}$ \\
\hline 5 & $\begin{array}{l}\text { Sofyan Rizal } \\
\text { (2006) }\end{array}$ & $\begin{array}{l}\text { Pengaruh Tingkat Kepuas- } \\
\text { an dan Kepercayaan Muza- } \\
\text { kki kepada LAZ terhadap } \\
\text { Perilaku Berzakat Muzakki }\end{array}$ & $\begin{array}{l}\text { LAZ, } \\
\text { Muzakki }\end{array}$ & $\begin{array}{l}\text { Kualitas pelayanan ter- } \\
\text { bukti secara signifikan ter- } \\
\text { hadap kepuasan dari } \\
\text { muzakki. Namun ditemu- } \\
\text { kan tidak ada pengaruh } \\
\text { yang signifikan kepuasan } \\
\text { muzakki dengan mem- } \\
\text { bayarkan zakatnya lang- } \\
\text { sung ke mustahiq }\end{array}$ \\
\hline 6 & $\begin{array}{l}\text { Muhammad } \\
\text { Yusrizal } \\
(2002)\end{array}$ & $\begin{array}{l}\text { Manajemen Zakat Infak } \\
\text { danSedekah }\end{array}$ & $\begin{array}{l}\text { Dompet } \\
\text { Dhu'afa' } \\
\text { Republika, } \\
\text { Amil }\end{array}$ & $\begin{array}{l}\text { UU No. } 38 \text { Tahun } 1999 \\
\text { memberikan kekuatan } \\
\text { hukum bagi Dompet Dhu- } \\
\text { afa' untuk menjalankan } \\
\text { peranannya lebih baik } \\
\text { dalam usaha pengentas- } \\
\text { an kemisiknan }\end{array}$ \\
\hline
\end{tabular}

\section{E. Sejarah Singkat Rumah Zakat Indonesia}

Pada tahun 1998, Abu Syauqi, salah satu tokoh da'i muda Bandung, bersama beberapa rekan di kelompok pengajian Majlis Ta'lim Ummul Quro sepakat membentuk lembaga sosial yang concern pada bantuan kemanusia- 
an. Pada tanggal 2 Juli 1998, terbentuklah organisasi bernama Dompet Sosial Ummul Quro (DSUQ), yang bertempat di Jl. Turangga No. 33 Bandung sekaligus sebagai tempat kajian. Jamaah pengajian semakin berkembang, Kemudian dipergunakanlah Masjid Al-Manaar Jl. Puter Bandung sebagai tempat kajian rutin.

Tahun 1999, dukungan masyarakat yang terus meluas mendorong dilakukannya pengelolaan organisasi ini lebih baik. Kantor sekretariat pindah ke Jl. Dederuk No. 30 Bandung, mendekat ke forum pengajian di Masjid AlManaar. Pencapaian donasi selama 1998-1999 terkumpul sebanyak Rp. 0,8 miliar.

Tahun 2000, animo masyarakat terhadap perlunya organisasi kemanusiaan semakin meningkat. Masyarakat memandang penting misi sosial ini diteruskan bahkan untuk kiprah yang lebih luas. Dirintislah program bea siswa pendidikan yatim dan ${ }^{\prime} u^{\prime} a f a^{\prime}$, layanan kesehatan, rehabilitasi masyarakat miskin kota, dll. Pemekaran mulai dilakukan dengan membuka kantor cabang Yogyakarta, Mei 2000 di Jl. Veteran No. 9. Cabang Bandung dipindah ke sekretariat awal di Jl. Turangga No. 33 Bandung. Donasi selama setahun terkumpul Rp. 2,1 miliar.

Pada tahun 2001 (Februari), kantor cabang Jakarta resmi berdiri di Jl. Ekor Kuning Rawamangun, Jakarta Timur. Pengumpulan donasi terbukukan sebesar Rp. 2,19 miliar.

Tahun 2002, identitas lembaga sebagai lembaga amil zakat semakin dikuatkan. Kantor Cabang Jakarta pindah ke Jl. Taruna No. 43 Pulogadung. Penerimaan donasi meningkat menjadi Rp. 4, miliar.

Tahun 2003, DSUQ berubah nama menjadi Rumah Zakat Indonesia DSUQ, seiring dengan turunnya SK Menteri Agama RI No. 157 pada tanggal 18 Maret 2003 yang mensertifikasi organisasi ini sebagai Lembaga Amil Zakat Nasional. Pada bulan Mei, Rumah Zakat Indonesia DSUQ hadir di ibukota Jawa Timur, Surabaya. Perolehan donasi terus meningkat menjadi Rp. 6,46 M.

Pada tahun 2004, Kantor Cabang Tangerang berdiri. Ekspansi mulai melebar ke Sumatera dengan didirikannya Kantor Cabang Pekanbaru, Riau, dimulainya pembangunan sistem teknologi informasi untuk peningkatan mutu pelayanan, sehingga hampir seluruh kantor cabang telah tersambung secara online di website www.rumahzakat.org menggantikan alamat situs sebelumnya di www.rumahzakat.net, menguatkan branding lembaga dengan 
nama Rumah Zakat Indonesia. Kepercayaan masyarakat semakin tumbuh, donasi terkumpul sebanyak Rp. 8,92 miliar.

Tahun 2005, pertumbuhan cabang meningkat pesat. Tsunami Aceh yang terjadi 26 Desember 2004 membuka akses Rumah Zakat Indonesia lebih berperan di Sumatera. Cabang-cabang baru pun dibuka, cabang Aceh, Medan, Padang, Palembang, dan Batam berdiri. Di Jawa, berdiri pula kantor cabang Semarang, ditambah jaringan Kantor Cabang Pembantu di Bekasi, Bogor, Depok, Jakarta Selatan, Cirebon, dan Solo. Cabang Pekanbaru juga berekspansi dengan memiliki Kantor Cabang Pembantu Duri dan Dumai. Sistem informasi lembaga mulai masuk ke jaringan online. Mulai transaksi online, absensi online, dan beberapa software keuangan.

Penerimaan donasi meningkat tajam khususnya dari bantuan masyarakat untuk program rehabilitasi pasca tsunami Aceh, tercatat Rp. 45,26 miliar donasi terkumpulkan.

Tahun 2006, regenerasi puncak pimpinan diestafetkan dari Ustadz Abu Syauqi beralih ke Virda Dimas Ekaputra. Babak sejarah baru 'Transformation From Traditional Corporate to Professional Corporate" dimulai. Kesadaran berzakat terus didorong dengan merilis kampanye: "When Zakat Being Lifestyle." Diluncurkanlah program "Gelar Budaya Zakat (GBZ) Menuju Indonesia Sadar Zakat 2008" pertama kali di 6 kota. Donasi berhasil terkumpul sebanyak Rp. 29,52 miliar.

Tahun 2007, pengembangan progam semakin disempurnakan termasuk dengan mengganti istilah Departemen Empowering menjadi Direktorat Program. Implementasi program mulai difokuskan hingga mengerucut pada empat induk yaitu EduCare, HealthCare, YouthCare, dan EcoCare. Pengelolaan program dilakukan dengan konsep terintegrasi dan berkelanjutan berbasis komunitas.

ICD merupakan tempat yang difokuskan untuk penyaluran yang terintegrasi yakni melalui pendidikan, kesehatan, pelatihan kepemudaan, dan pemberdayaan ekonomi secara terpadu berbasis komunitas. Dengan Mustahiq Relation Officer sebagai SDM pendamping, ICD menjadi pusat penyaluran program sehingga lebih terukur, dan terkontrol. Di tahun ini pula Rumah Zakat Indonesia melebarkan layanan program pendidikan dengan menyelenggarakan Sekolah Dasar Juara yang bersifat gratis. Guru-guru terbaik dipilih untuk mendidik calon pemimpin bangsa. Program komunikasi di- 
kembangkan lebih massif melalui televisi. Diluncurkanlah TV Commercial perdana berjudul "Saya Percaya Rumah Zakat" dengan menggandeng endorser Helmy Yahya. Acara "Gelar Budaya Zakat (GBZ) Menuju Indonesia Sadar Zakat 2008" kembali digelar, kali ini diselenggarakan di 10 kota. Ternyata hasil komunikasi dan focusing program bekorelasi positif terhadap pencapaian donasi, terkumpul Rp. 50,16 miliar.

Tahun 2008, Rumah Zakat Indonesia berkeinginan kuat untuk memantapkan program-program pemberdayaan. Dukungan dan kepercayaan masyarakat menguatkan lembaga untuk semakin fokus kepada sebuah rekayasa peradaban besar yang sejak awal telah diimpikan, yakni "transformasi mustahiq ke muzakki". Wujud nyata usaha lembaga adalah dengan meluaskan jaringan pengembangan usaha kecil dan mikro di 18 kota.

Tidak hanya itu, Rumah Zakat Indonesia pun menyelenggarakan pelatihan-pelatihan motivasi dan keterampilan dalam wadah Youth Development Center. Pelatihan motivasi ini memegang peranan penting karena karakter, pola pikir, dan sikap yang kontra produktif menyumbangkan andil besar dalam kelanggengan sebuah kemiskinan. Dan yang tidak kalah penting adalah pendampingan masyarakat dilakukan oleh 28 Mustahiq Relation Officer (MRO) dengan didukung para relawan.

Pembelajaran untuk menjadi organisasi yang amanah dan professional terus dilakukan, salah satunya dengan penguatan program-program Human Capital. Diluncurkanlah program seperti EAZI (Executive Amil Zakat Indonesia), ADP (Amil Development Program), ACTPRO (Acceleration Program) dan sebagainya. Kegiatan peningkatan kapasitas ini terbukti efektif kompetensi memenuhi tuntutan profesi dan masyarakat. Kepercayaan terus tumbuh, dari pencapaian donasi berhasil terkumpulkan donasi sebesar Rp. 71,40 miliar. Untuk memberikan edukasi lebih luas kepada masyarakat tentang zakat dan filantropi, roadshow Gelar Budaya Zakat dilakukan, kali ini hadir di 19 kota.

Tahun 2009 menjadi tahun pertama pasca 10 tahun pertama milestone Rumah Zakat Indonesia. Guna penguatan organisasi dikokohkanlah organisasi baru pemberdayaan, yaitu: Rumah Sehat Indonesia (pengelola program kesehatan), Rumah Juara Indonesia (pengelola program pendidikan), Rumah Mandiri Indonesia (pengelola program kemandirian ekonomi). Peningkatan jumlah unit layanan terus dilakukan, hingga akhir tahun telah berdiri 8 
Sekolah Juara, 7 Rumah Bersalin Gratis. Tahun 2009 bisa disebut sebagai tahun ekspansi, mengingat dalam 1 semester langsung dibuka 14 cabang baru sehingga menambah total jumlah jaringan sebanyak 45 kantor. Pengelolaan yang semakin baik mendapat apresiasi dari masyarakat. antara lain award dari Karim Business Consulting yang menempatkan Rumah Zakat Indonesia sebagai LAZNAS Terbaik dalam ISR Award (Islamic Social Responsibility Award 2009). Penghargaan juga datang dari IMZ (Indonesia Magnificence of Zakat) yang menganugerahi Rumah Zakat Indonesia sebagai The Best Organization in Zakat Development. Pencapaian donasi tumbuh semakin baik, tercatat Rp. 107, 3 miliar berhasil dikumpulkan dan menjadikan Rumah Zakat Indonesia sebagai organisasi pengelola zakat terbesar dalam pengumpulan donasinya se-Indonesia.

Krisis global tahun 2009 banyak diprediksikan mulai pulih pada tahun 2010, namun tantangan sosial dan ekonomi tak lebih mudah dihadapi. Rumah Zakat Indonesia menyikapi hal ini dengan melakukan rangkaian adaptasi dan perubahan menuju organisasi berskala global. Pada 5 April 2010, resmi diluncurkanlah brand baru "Rumah Zakat" menggantikan brand sebelumnya "Rumah Zakat Indonesia". Dengan mengusung tiga brand value baru: Trusted, Progressive dan Humanitarian, organisasi ini menajamkan karakter menuju "World Class Socio-Religious Non Governance Organization (NGO)". Sharing Confidence diangkat menjadi positioning. "Dengan keyakinan yang kuat untuk berbagi dan menciptakan keluarga global yang lebih baik, Rumah Zakat berdaya upaya untuk menjadi organisasi terdepan di region yang menjamin program efektif dan berkesinambungan dalam memberdayakan masyarakat untuk mencapai kehidupan yang lebih baik."

Untuk memperkuat perubahan ini diluncurkan pula gerakan Merangkai Senyum Indonesia, sebuah rangkaian kegiatan untuk memperbaiki Indeks Pembangunan Manusia (IPM) Indonesia, lebih khususnya dalam bidang pendidikan, kesehatan dan kelayakan hidup.

Adapun sejarah Rumah Zakat di Jawa Tengah dimulai dari pembukaan kantor cabang Semarang di bulan Mei 2005 bersamaan itu pula Rumah Zakat cabang Solo juga di buka. Program pertama yang digulirkan adalah Beasiswa untuk Anak Yatim dan Dhu'afa'/Program KSAB (Kembalikan Senyum Anak Bangsa) dan Baksos Siaga Sehat dan Siaga Gizi. Seiring dengan itu, kantor pusat mendatangkan unit mobil ambulan untuk program mobil ambulan 
gratis untuk masyarakat kota Semarang. Program ambulan ini cukup populis dan menjadi branding yang luar biasa bagi Rumah Zakat Cabang Semarang.

Dukungan dan simpatik masyarakat kota Semarang atas kepercayaan terhadap Rumah Zakat Cabang Semarang semakin bertambah, di bulan Mei 2007 hadir RBG (Rumah Bersalin Gratis) dan di tahun 2010 hadir pula Sekolah Dasar Juara gratis bagi anak yatim dan du'afä'. Program dan layanan Rumah Zakat akan semakin banyak bergulir seiring dengan kepercayaan dan dukungan masyarakat kota Semarang.

Adapun untuk pemberdayaan KUKMI (Kelompok Usaha Kecil Menengah) ada 50 yang telah terdampingi. Ada perubahan akhlak dan kesadaran beragama dan $20 \%$ dari kelompok yang terdampingi usahanya semakin maju dan semangat. Ada semangat dan harapan ketika kita menolong saudara kita Muslim yang lemah maka Allah SWT akan menolong dan memudahkan kerja kita.

\section{F. Faktor-faktor yang Mempengaruhi Responden Menyalurkan Dana ZIS pada Rumah Zakat Indonesia}

Berdasarkan hasil penyebaran kuesioner penelitian, 32,26\% menunjukkan bahwa RZI dapat dipercaya, dan 29,03\% menunjukkan bahwa RZI transparan dan akuntabel. Besarnya responden menyatakan bahwa RZI dapat dipercaya, karena setiap kegiatan RZI (pengumpulan maupun pendistribusian ZIS) selalu diinformasikan secara transparan dan akuntabel pada media, baik website maupun media informasi lainnya, dan setiap donatur (muzakki) dapat secara mudah mengontrol dana ZIS, hal ini mengakibatkan responden percaya pada manajemen pengelolaan ZIS pada Rumah Zakat Indonesia. Selain itu ada beberapa alasan RZI dipercaya oleh masyarakat:

1. RZI telah berdiri hampir 11 tahun dan menjadi salah satu perintis pengelolaan zakat, infaq, shadaqah dan filantropi Islam secara profesional, dikelola sebagai sebuah profesi setiap hari, 6 hari kerja, dengan sumber daya manusia $90 \%$ di bawah 35 tahun, mayoritasnya sarjana dan diploma dari berbagai perguruan tinggi terkemuka.

2. Indonesia adalah negara bahari dan kepulauan karenanya RZI hadir tak hanya di pulau Jawa namun menyebar dengan jaringan terbesar dibanding lembaga pengelola sejenis. Hingga Mei 2009, RZI telah memiliki 
44 jaringan kantor di 38 kota besar di Jawa, Sumatera, Kalimantan, Sulawesi, dan Papua dengan pola hubungan pusat-cabang yang kokoh dan terintegrasi.

3. RZI mengembangkan manajemen dana zakat, infaq, shadaqah, dan dana kemanusiaan lainnya berbasis komunitas, baik per kecamatan maupun kelurahan yang disebut ICD (Integrated Community Development). Setiap ICD ditangani oleh minimal 1 orang Mustahiq Relation Officer (MRO) dengan didukung 3-5 relawan yang mengembangkan 4 program utama; EduCare (fokus: pendidikan dasar), HealthCare (fokus: kesehatan ibu dan anak), EcoCare (fokus: pemberdayaan dan pendampingan usaha), YouthCare (fokus: pemberdayaan pemuda dan pendampingan masyarakat). Kini telah terbentuk 227 ICD dimana setiap ICD terbina 100-200 Kepala Keluarga, dengan 14 Integrated Community Development (ICD) Centre yang tersebar di 14 kota.

4. Program yang dikembangkan RZI cukup sederhana, populis namun terasa di masyarakat. Ini bisa dilihat dari program unggulan seperti program mobil jenazah gratis dimana kini telah tersedia 45 unit mobil jenazah dan ambulan yang siap melayani masyarakat secara gratis. Program-program nyata inilah kiranya yang ikut menguatkan 85.057 donatur semakin percaya terlibat dalam program ini melalui Rumah Zakat Indonesia.

5. Zakat masyarakat terdayagunakan secara optimal dan nyata melalui berdirinya program centre seperti:

a. Delapan (8) unit Sekolah Juara (sekolah dasar unggulan, gratis bagi siswa kurang mampu) di Bandung, Cimahi, Jakarta, Pekanbaru, Surabaya, Yogyakarta, Jakarta Selatan, Medan.

b. Tiga belas (13) Pusat Pengembangan Potensi Anak (P3A) di hampir seluruh cabang RZI, dengan 455 anak asuh. Secara reguler Departemen EduCare juga mengelola santunan beasiswa untuk 20.155 anak asuh. Minimal sebulan sekali diselenggarakan pembinaan Kids Learning Centre yang diikuti oleh 16.124 anak asuh tersebar di 228 ICD dengan didukung oleh 698 pementor aktif.

c. Tujuh (7) unit Rumah Bersalin Gratis (RBG) di Bandung, Jakarta, Semarang, Yogya, Medan, Pekanbaru, dan Surabaya. Tahun ini juga akan dibuka RBG baru di empat kota. Cabang-cabang yang belum 
memiliki RBG kini juga telah mampu melayani kesehatan ibu dan anak melalui program Layanan Bersalin Gratis (LBG), bekerjasama dengan bidan mitra.

d. Delapan belas (18) unit Koperasi Syariah "Mozaik" di 17 kota.

e. Satu (1) unit Youth Development Centre di Bandung sebagai pusat pelatihan entrepreneurship para pemuda yang tergabung dalam relawan dan Integrated Community Development.

6. Pengelolaan zakat selain harus maju juga tetap harus sesuai dengan koridor syariah (sharia comply). RZI secara rutin berkonsultasi dengan Dewan Pengawas Syariah Rumah Zakat Indonesia, Ustadz Kardita Kintabuwana, Lc, MA yang merupakan lulusan Jami'ah al-Islamiyah Madinah dan Direktur Ma'had al-Imarat Bandung. Selain juga secara rutin bersama referensi syariah Ustadz Dr. Setiawan Budi Utomo, Lc yang juga selaku anggota Dewan Syariah Nasional-MUI.

7. Pengelolaan dana masyarakat dilakukan secara amanah didukung teknologi komunikasi modern menghubungkan seluruh jaringan kantor secara online. Setiap perkembangan donasi bisa terpantau secara real time. Saat ini juga dikembangkan Mustahiq Information System (MUIS) dimana para penerima manfaat terdata secara lengkap sehingga pemantauan dan pembinaan lebih mudah dan akurat.

8. Badan hukum boleh berupa yayasan tapi budaya kerja full corporate. Presensi kehadiran dilakukan secara online, mulai masuk pagi, masuk setelah jam istirahat siang, hingga jam kepulangan. Setiap yang terlambat dikenakan denda bervariasi mulai Rp. 100 ribu hingga Rp. 750 ribu per hari meskipun hanya terlambat 1 detik. Sistem reward dan punishment berjalan baik dengan dukungan sistem Human Resource Information System (HRIS) yang online dan transparan.

9. Meskipun utamanya membidik segmen personal, RZI juga telah dipercaya banyak perusahaan dan komunitas. Tercatat hingga awal Maret 2009, 460 perusahaan nasional dan daerah (beraset Rp. 500 juta ke atas) bergabung menjadi mitra. RZI juga mendapat apresiasi positif dari PBB (United Nations) dalam program-programnya yang banyak mendukung Millenium Development Goals (MDGs). 
10. Para donatur dan masyarakat secara umum dapat mengakses layanan secara mudah dengan beragam kemudahan berdonasi. Baik via visiting counter, dijemput oleh ZIS Consultant, via ATM, online payment, mobile banking, internet banking, donasi via kartu debet dan kartu kredit, autodebet, maupun donasi via sms. Kemudahan ini juga didukung layanan host to host dengan perbankan dan mitra jasa pembayaran. Mitra online juga bisa berkonsultasi seputar zakat dan layanan via website http://www. rumahzakat.org maupun SMS centre di nomor 08157300 1555, email centre di welcome@rumahzakat.org, call centre 08041001000.

\section{G. Pengelolaan dan Pendistribusian Dana ZIS pada Rumah Zakat Indonesia dalam Upaya Pengentasan Kemiskinan di Jawa Tengah}

Pengelolaan dan pendistribusian dana ZIS pada RZI dengan mengembangkan beberapa program antara lain: (1) Pendampingan Masyarakat; (2) Integrated Community Development (ICD); (3) Pengembangan Kapasitas Pemuda; (4) Siaga Bencana.

ICD (Integrated Community Development) merupakan program unggulan yang dikembangkan oleh Rumah Zakat Indonesia yang merupakan pusat pemberdayaan masyarakat berbasis komunitas di wilayah kecamatan/ kelurahan. Setiap ICD didampingi oleh seorang MRO (Mustahiq Relation Officer) yang berfungsi sebagai penggerak, pendamping, fasilitator, dinamisator bahkan dai yang membantu memastikan 4 rumpun program utama RZI diterima dengan baik di masyarakat. Setiap MRO tinggal di komunitas tersebut mengelola 100-250 keluarga.

Integrated Community Development (ICD) merupakan pendekatan multi aspek yang digulirkan RZI untuk mengentaskan kemiskinan para mustahiqnya secara terpadu dengan basis kerja wilayah tertentu (skup kelurahan). Di Provinsi Jawa Tengah pada bulan Maret 2010 sebesar 5,369 juta orang (16,56\%). Dibandingkan dengan penduduk miskin pada Bulan Maret 2009 yang berjumlah 5,726 juta orang $(17,72 \%)$, berarti jumlah penduduk miskin turun sebanyak 356,53 ribu orang. Hal ini secara tidak langsung, RZI berperan dalam pengentasan kemiskinan di Jawa Tengah melalui pemberdayaan dana ZIS. 
Penyaluran bantuan RZI dilakukan melalui program-program dalam bidang pendidikan, kesehatan, kepemudaan (kerelawanan) serta bidang ekonomi. Kondisi penyaluran saat ini masih dilakukan secara tersebar sesuai mustahiq berada untuk setiap program, hal ini memberikan kesulitan dalam memberikan pengukuran keberhasilan program. Sedangkan tujuan program ICD adalah: (1) Membantu mustahiq untuk survive di tengah kekurangan materi yang dimiliknya. (2) Terpantaunya perkembangan kesejahteraan mustahiq selama dalam binaan ICD; (3) Tersadarkannya masyarakat terhadap tanggung jawab lokal dalam mengentaskan kemiskinan di wilayahnya (ICD) (4) Terentaskannya mustahiq dari garis kemiskinan sehingga bisa berubah kesejahteraannya pada level muzakki.

RZI telah banyak dipercaya oleh mitra baik perseorangan, lembaga atau perusahaan (nasional dan daerah) RZI juga mendapat apresiasi positif dari PBB (United Nations) dalam program-programnya yang banyak mendukung Millenium Development Goals (MDGs) dalam rangka pengentasan kemiskinan. Tujuh dari delapan program Millenium Development Goals (MDGs) telah dilakukan Rumah Zakat Indonesia. Antara lain: penghapusan kemiskinan, pendidikan untuk semua, persamaan gender, penurunan angka kematian anak, peningkatan kesehatan ibu, pelestarian lingkungan hidup, kerjasama global. Melalui program-programnya, Rumah Zakat Indonesia semakin kokoh melalui pemantauan lebih detail di setiap komunitas pemberdayaan terpadu. Diharapkan usaha ini sejalan dengan tujuan pembangunan millenium (MDGs) yang menargetkan pada tahun 2015, kemiskinan bisa ditekan hingga 50\%.

\section{H. Kontrol Rumah Zakat Indonesia (RZI) dalam Perdistribusian ZIS}

RZI mengontrol pendistribusian ZIS dalam upaya pengentasan kemiskinan dengan menetapkan Standard Operating Procedure (SOP) selain itu setiap program donator akan menerima berbagai laporan sebagai bentuk trasparansi dan akuntabilitas dalam pengelolaan dan pendistribusian ZIS pada Rumah Zakat Indonesia. Untuk Integrated Community Development (ICD). Program ini dapat ditawarkan kepada donatur corporate dengan mengusung corporate. Untuk mengontrol keberhasilan program ini serta sebagai bentuk transparansi maka Integrated Community Development (ICD) 
mempunyai Standard Operating Procedure (SOP) yang dapat dijelaskan pada gambar 2 .

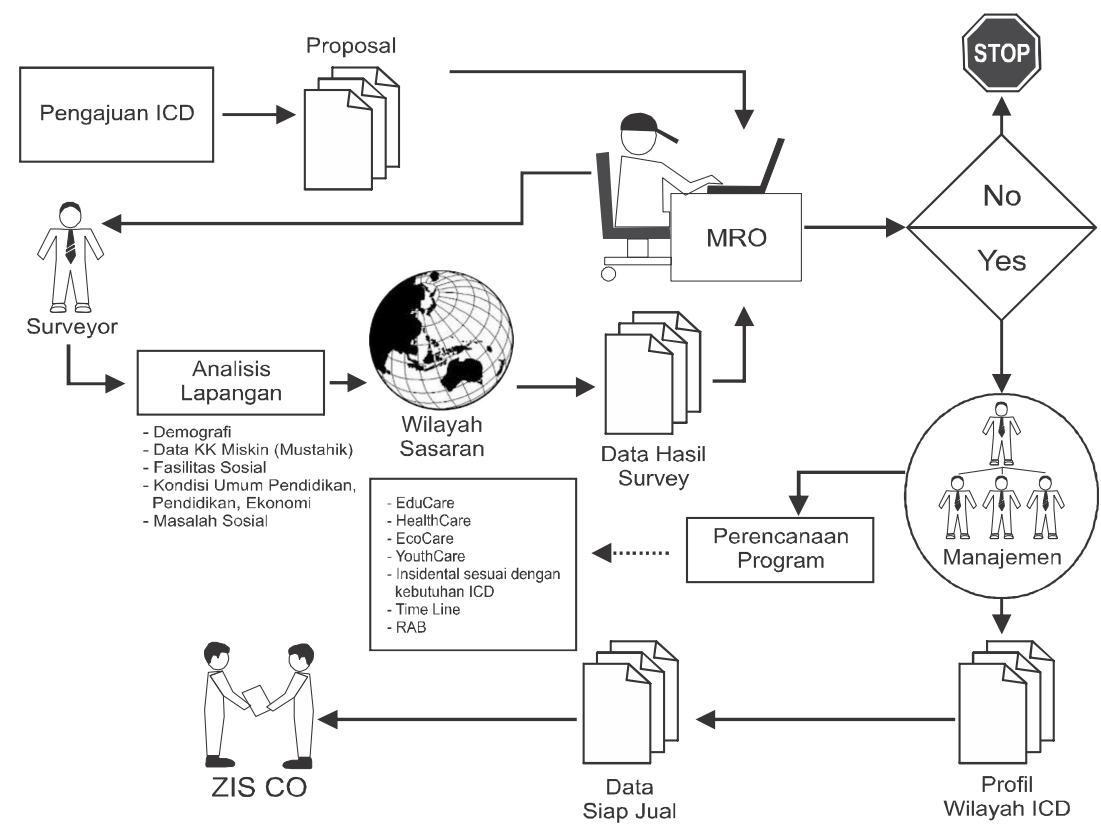

Gambar 2.

Standard Operating Procedure (SOP)

\section{Model Pengelolaan dan Pendistribusian Zakat Berdasarkan Hasil Penelitian}

Hasil penelitian menujukkan bahwa dalam pengelolaan zakat yang dihimpun RZI dari suatu daerah, dana siap salurnya untuk daerah itu sendiri. Hasil penghimpunan dana ZIS dari berbagai cara yang memudahkan untuk membayar ZIS, dicatat terpusat, dengan pendistribusian di setiap daerah hal ini ditujukan untuk memudahkan audit keuangan secara konsolidasi dan transparan. Dana Pengelola ( $a m i l$ ) yang dihasilkan dari penghimpunan, dapat disubsidisilangkan ke kota-kota yang membutuhkan.

Prosentase distribusi ke program tergantung evaluasi dan kebutuhan masyarakat standar yang digunakan ZIS. Alokasi dana 12,5\% dana penge- 
lola, $10 \%$ cadangan penyaluran dan $77,5 \%$ dana siap salur. Sedangkan alokasi untuk program kegiatan dalam upaya pengentasan kemiskinan untuk program EcoCare sebesar 20\%, ICD sebesar 5\%, YouthCare sebesar 10\%, EduCare sebesar 22\%, HealthCare sebesar 34\% serta Nasional sebesar 9\%. Sebagai bentuk transparansi dan akuntabilitas, RZI melaporkan progres repot terhadap program-program kegiatan yang telah dilaksanakan pada donatur.

\section{J. Kesimpulan}

Model pengelolah dan pendistribusian ZIS yang amanah, transparan, dan profesional telah dilakukan oleh Rumah Zakat Indonesia (RZI), sehingga RZI merupakan salah satu badan pengelola ZIS yang mendapatkan kepercayaan masyarakat. Melalui pengembangan program ICD yang terintegrasi, maka pendistribusian ZIS dapat memberdayakan masyarakat miskin. Untuk mengontrol program-program pemberdayaan, RZI telah menetapkan SOP dalam rangka mengontrol program-program pemberdayaan zakat yang transparan dan akuntabel.[w] 


\section{BIBLIOGRAFI}

Abdurrachman Qadir, Zakat dalam Dimensi Mahdah dan Sosial, Jakarta: RajaGrafindo Persada, 2001.

Ali, Nuruddin M., "Zakat (Pajak) sebagai Instrumen dalam Kebijakan Fiskal,” Tesis, tidak diterbitkan, Yogyakarta: Program Pascasarjana IAIN Sunan Kalijaga Yogyakarta, 2003.

Bappenas, Perspektif Teoritis Konsep Dasar Pengembangan Ekonomi Lokal, Jakarta: Bappenas, 1993.

Blank, "Poverty, Policy and Palce: How Poverty and Policies to Alleviate Poverty are Shaped by Local Characteristics," RPRC Working Paper, 2004.

DSNI Amanah, "Dapatkah Zakat Menyelesaikan Kemiskinan," dikutip dari http://www.dsniamanah.or.id, diakses tanggal 10 Oktober 2010.

Jurjani, Ali ibn Muhammad, Kitab al-Ta'rīf, Beirut: Dar al-Kutub al-'Ilmiyah.

Mudrajad Kuncoro, Ekonomi Pembanguan: Teori, Masalah, dan Kebijakan, Yogyakarta: UPP AMP-YKPN, 2003.

Qardhawi, Yusuf, Kiat Islam Mengentaskan Kemiskinan, terj, Jakarta: Gema Insani Press, 1995.

Ravallion, M., Poverty Comparisons. World Bank, 2001.

Rumah Zakat Indonesia, "Profil Rumah Zakat Indonesia," dikutip dari http://www. rumahzakat.org, diakses pada tanggal 23 Maret 2011.

Sayyid Sabiq, Fiqh al-Sunnah, Jilid I, Beirut: Dar al-Fikr, 1982.

Setyawan, Setu, Pengukuran Kinerja Anggaran Keuangan Daerah Pemerintah Dilihat dari Prespektif Akuntabilitas, Yogyakarta: UGM, 2006.

Sofyan Effendi, "Prinsip-prinsip Analisa Data," dalam Masri Singarimbun, Metode Penelitian Survei, Jakarta: LP3ES, 1988.

World Bank, World Bank Report, 2000/2001: Attacking Poverty, Oxford: Oxford University Press, 2001. 
